\title{
BMJ Open Association of rule of law and health outcomes: an ecological study
}

\author{
Angela Maria Pinzon-Rondon, ${ }^{1}$ Amir Attaran, ${ }^{2}$ Juan Carlos Botero, ${ }^{3}$ \\ Angela Maria Ruiz-Sternberg ${ }^{1}$
}

To cite: Pinzon-Rondon AM, Attaran A, Botero JC, et al. Association of rule of law and health outcomes: an ecological study. BMJ Open 2015;5:e007004.

doi:10.1136/bmjopen-2014007004

- Prepublication history and additional material is available. To view please visit the journal (http://dx.doi.org/ 10.1136/bmjopen-2014007004).

Received 29 October 2014 Revised 6 March 2015 Accepted 15 July 2015

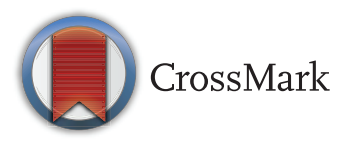

${ }^{1}$ Escuela de Medicina y Ciencias de la Salud, Universidad del Rosario, Bogotá, Colombia

${ }^{2}$ Faculties of Law and Medicine, Canada Research Chair in Law, Population Health and Global Development Policy, University of Ottawa, Ottawa, Ontario, Canada

${ }^{3}$ The World Justice Project, Washington, DC, USA

Correspondence to Dr Angela Maria Pinzon-Rondon; angela_pinzon@hotmail.com

\section{ABSTRACT}

Objectives: To explore whether the rule of law is a foundational determinant of health that underlies other socioeconomic, political and cultural factors that have been associated with health outcomes.

Setting: Global project.

Participants: Data set of 96 countries, comprising $91 \%$ of the global population.

Primary and secondary outcome measures: The following health indicators, infant mortality rate, maternal mortality rate, life expectancy, and cardiovascular disease and diabetes mortality rate, were included to explore their association with the rule of law. We used a novel Rule of Law Index, gathered from survey sources, in a cross-sectional and ecological design. The Index is based on eight subindices: (1) Constraints on Government Powers;

(2) Absence of Corruption; (3) Order and Security;

(4) Fundamental Rights; (5) Open Government;

(6) Regulatory Enforcement, (7) Civil Justice; and

(8) Criminal Justice.

Results: The rule of law showed an independent association with infant mortality rate, maternal mortality rate, life expectancy, and cardiovascular disease and diabetes mortality rate, after adjusting for the countries' level of per capita income, their expenditures in health, their level of political and civil freedom, their Gini measure of inequality and women's status $(p<0.05)$. Rule of law remained significant in all the multivariate models, and the following adjustment for potential confounders remained robust for at least one or more of the health outcomes across all eight subindices of the rule of law. Findings show that the higher the country's level of adherence to the rule of law, the better the health of the population.

Conclusions: It is necessary to start considering the country's adherence to the rule of law as a foundational determinant of health. Health advocates should consider the improvement of rule of law as a tool to improve population health. Conversely, lack of progress in rule of law may constitute a structural barrier to health improvement.

\section{INTRODUCTION}

It is common to assess the public's health in terms of risk factors, medical technologies, health systems or, most recently, social

\section{Strengths and limitations of this study}

In a large sample of countries, we found a statistically significant and robust correlation between the rule of law and various health outcomes.

- This research has implications on the Millennium Development Goals (MDG), since it addresses the interplay between health (MDG 3 and 6) and rule of law (post-2015 goal 16).

- While we cannot ascertain causation within this study's design-correlation is not causationplausible causal mechanisms exist.

- Using a national level of analysis, there can be variations in the rule of law within countries. This study does not provide a final word on the relationship between legal institutions and health.

determinants-all of which are clearly important and command resources for research and intervention. ${ }^{1}$ However, these seemingly distinct, separately conceived determinants of public health are actually underpinned by factors that are more crosscutting and fundamental-or what might be called 'determinants of determinants'. An example is economic strength: the WHO's Commission on Macroeconomics and Health persuasively demonstrated that public budgetary decisions, made within a given envelope of per capita income, were tightly correlated with health status, and that this correlation had several plausible causal mechanisms through expenditures on medical technologies and health systems, mitigation of risk factors and policies supportive of social equity. $^{2}$ Owing to this research, macroeconomics is now widely accepted as a foundational determinant of health, pervading but still not eclipsing the other determinants, which are nearer the coalface of public health practice.

The aim of the study is to examine the association of the rule of law and health indicators at the country level. In this paper, we examine the hypothesis that, similar to macroeconomics, the rule of law is 
overlooked as a cross-cutting 'determinant of determinants'. There are several plausible causal connections between law and the various, more familiar determinants of health (box 1).

The rule of law corresponds roughly to the idea that a society both possesses and observes formal codes or norms that effectively constrain individual, institutional and governmental behaviour. While definitions vary, most acknowledge these components as core defining attributes of the rule of law: (1) that governments, individuals and private entities are not above the law; (2) that the laws are clear, publicised, stable and applied evenly to protect fundamental rights; (3) that laws are enacted, administered and enforced through accessible, fair and efficient processes and (4) that justice or dispute resolution is delivered timely to the community. ${ }^{3-8}$ Societies that institutionalise and govern themselves by these conditions tend to thrive because they possess a rules-based stability, and avoid self-harm through arbitrary actions such as corruption and violence. ${ }^{4-10}$ In other words, the desirable condition that is commonly referred to as 'good governance' depends heavily on securing adherence to the rule of law.

However, unlike macroeconomic qualities, a society's rule of law situation is difficult to measure..$^{5-8} 11{ }^{12}$ Laws are inherently textual and qualitative by nature, and lack similarly clear-cut measures that exist for assessing population health (eg, mortality, disease incidence) or for economies (eg, gross domestic product (GDP) growth, inflation). Furthermore, the true effectiveness of laws depends not just on their content or plain wording, but also on societal attitudes, such as the effort put into law enforcement. Yet even with these apparent vagaries, several studies, each using different definitions, agree to a striking extent that a strong positive correlation between better rule of law and rising wealth exists: for example, improving governance by one SD seems to triple wealth. ${ }^{13-16}$

Might there be a similarly robust yet overlooked correlation between better rule of law and superior public health outcomes? In this study, we test this hypothesis using a new measure of the rule of law: The World Justice Project's (WJP) Rule of Law Index. Exploring a data set including 96 countries drawn from all income levels and regions of the globe, and comprising over $90 \%$ of the global population, ${ }^{17}$ we study the relationship between the Rule of Law Index and disease statistics representative of the UN Millennium Development Goals (child mortality and maternal mortality), the WHO Non-Communicable Disease Action Plan (cardiovascular disease and diabetes) and crude life expectancy at birth (LE).

\section{Box 1 Examples of the law as a determinant of health}

\section{Developed country examples}

1. CORRUPTION-In the USA, the Columbia/ Hospital Corporation of America (HCA) hospital network engaged in corrupt practices such as kickbacks to referring doctors, setting targets for complication rates (which Medicare reimburses at higher prices) and false billing. Whistleblowers used the False Claims Act to sue Columbia/HCA. The company admitted its crimes and settled with the US government for over US\$1 billion, and the whistleblowers pocketed millions of that. The law empowers private whistleblowers to supplement government law enforcement and rewards them generously for their risk. ${ }^{47}$

2. ENFORCEMENT OF HEALTH RIGHTS - In Canada, after an epidemic of fatal overdoses among injection drug users in Vancouver, the government licensed researchers to operate a medically supervised injection site on a trial basis. Trials conducted at that site demonstrated major reductions in overdose fatalities and HIV and hepatitis incidence. When a new, conservative government refused to renew the site's license, drug users and advocates sued and alleged a violation of the constitutional right to health. The Supreme Court of Canada ordered the government to reissue the license, and laid down parameters under which other such safe injection sites may operate. $^{48}$

3. EQUITY - In Saudi Arabia, women broadly lack equality of rights and social opportunities or protection under law. Saudi women cannot be admitted to government hospitals without a male guardian, and have limited autonomy over care, particularly in reproduction. These constraints are reflected in many health comes, such as a much higher rate of obesity in women compared to men, and below-average rates of maternal and child mortality ratio compared to other developed countries. ${ }^{49}$

Developing country examples

1. CORRUPTION - In Kenya, employees of the National AIDS Control Council (NACC) used public funds for private gain. The director, Margaret Gachara, paid herself a salary sevenfold higher than her entitlement, and other NACC employees diverted funds for private utility bills. Some $\$ 48$ million of British aid money was unaccounted for. Ms Gachara was ordered to refund $\$ 340000$ and sentenced to jail, but the legal outcome was subverted by a presidential pardon that freed her after only a few months. The other officials went unpunished. ${ }^{47}$

2. ENFORCEMENT OF HEALTH RIGHTS-In India, the government's long failure (or refusal) to pass tobacco control legislation led to a court challenge, in which it was argued that secondhand smoking violated the right to life in the Constitution. The High Court agreed and ordered a ban on smoking in public places in Kerala. Later, the Supreme Court of India extended the ban nationwide, and the government followed up with comprehensive tobacco control legislation. ${ }^{50}$

3. EQUITY - in Brazil, where overall health equity is poor, the federal government in 2003 introduced a conditional cash transfer for lowincome households, known as Bolsa Familia, which legally and administratively merged four already existing social benefits spread across government departments. Eligible families qualified for payments of up to $\$ 175$ monthly if children were kept in school and received routine paediatric care. Child mortality of poverty-related causes dropped significantly in the new administrative scheme, with the largest gains in municipalities that made most use of Bolsa Familia. ${ }^{51}$ 


\section{METHODS}

We used a novel Rule of Law Index, gathered from survey sources, in a cross-sectional and ecological design. We obtained all statistical data used in this study from previously published sources for the most recent year (between 2009 and 2012), using the UN sources for health and economic data, supplemented with data on political freedom and the rule of law from Freedom House and the WJP, respectively. The limitations of the individual sources allowed for a merged database of complete data in 96 countries, comprising $91 \%$ of the global population, which was used in bivariate and multivariate regression models. These include low-income, middle-income and high-income countries from all continents: Albania, Argentina, Australia, Austria, Bangladesh, Belarus, Belgium, Bolivia, Bosnia and Herzegovina, Botswana, Brazil, Bulgaria, Burkina Faso, Cambodia, Cameroon, Canada, Chile, China, Colombia, Cote d'Ivoire, Croatia, the Czech Republic, Denmark, the Dominican Republic, Ecuador, Egypt, El Salvador, Estonia, Ethiopia, Finland, France, Georgia, Germany, Ghana, Greece, Guatemala, Hungary, India, Indonesia, Iran, Italy, Jamaica, Japan, Jordan, Kazakhstan, Kenya, Kyrgyzstan, Lebanon, Liberia, Macedonia, Madagascar, Malawi, Malaysia, Mexico, Moldova, Mongolia, Morocco, Nepal, the Netherlands, New Zealand, Nicaragua, Nigeria, Norway, Pakistan, Panama, Peru, the Philippines, Poland, Portugal, Romania, Russia, Senegal, Serbia, Sierra Leone, Singapore, Slovenia, South Africa, South Korea, Spain, Sri Lanka, Sweden, Tanzania, Thailand, Tunisia, Turkey, the United Arab Emirates, Uganda, Ukraine, the UK, the USA, Uruguay, Uzbekistan, Venezuela, Vietnam, Zambia and Zimbabwe.

The Rule of Law Index used in this study is a new one created by the WJP. Briefly, the Rule of Law Index 20122013 reports knowledge, attitude and perceptions based on two surveys: a general population poll of about 1000 respondents per country, and a Delphi-like survey of over 2500 practising professionals or academics in civil and commercial law, criminal justice, labour law and public health. The index comprises information on 528 variables organised in 50 indicators and eight thematic subindices: (1) Constraints on Government Powers; (2) Absence of Corruption; (3) Order and Security; (4) Fundamental Rights; (5) Open Government; (6) Regulatory Enforcement, (7) Civil Justice; and (8) Criminal Justice (table 1). ${ }^{17}$ Initially, we conducted a principal components factor analysis based on eigenvalues greater than one of the eight rule of law subindices, finding a single component (see online supplementary appendix). Since the analysis provided evidence of uniqueness underlying the eight subindices, we used, in addition to the individual factors, a scaled arithmetic mean of the eight subindices as an aggregated rule of law indicator (with 1 being perfect adherence to the rule of law and 0 being an absence of the rule of law).

Our other data sources are established ones. The WHO data were used for infant mortality rate (IMR),
Table 1 Brief definition of rule of law index subfactors

\begin{tabular}{|c|c|}
\hline d & id \\
\hline jvernment & -governmental check and \\
\hline owers & ances on the government powers \\
\hline $\begin{array}{l}\text { bsence of } \\
\text { orruption }\end{array}$ & $\begin{array}{l}\text { Control of corruption in all branches } \\
\text { of government }\end{array}$ \\
\hline surity & $\begin{array}{l}\text { Control of crime, civil conflicts and } \\
\text { the use of violence }\end{array}$ \\
\hline $\begin{array}{l}\text { Fundamental } \\
\text { Rights }\end{array}$ & $\begin{array}{l}\text { Equal protection, right to life and } \\
\text { security, freedom of speech, } \\
\text { assembly, religion and due process } \\
\text { of law }\end{array}$ \\
\hline Dpen & Right to information and petition \\
\hline eg & forcement \\
\hline Enf & \\
\hline Civil & $\begin{array}{l}\text { Impartial and effective delivery of } \\
\text { civil justice }\end{array}$ \\
\hline Crimin & $\begin{array}{l}\text { Impartial and effective delivery of } \\
\text { criminal justice }\end{array}$ \\
\hline
\end{tabular}

maternal mortality rate (MMR), LE and cardiovascular disease and diabetes mortality rate (CVMR+DMR). The former two are the same data used for Millennium Development Goals 4 and 5 (the probability of dying between birth and age 1/1000 live births in 2011, and the number of maternal deaths per 100000 live births in 2010), and the natural logarithm of these variables was used in the regression models. Data on life expectancy are that for males and females combined at birth in 2009. CVMR and DMR are the same as those used for the WHO Non-Communicable Disease Action Plan, but the crude mortality rates per 100000 people were combined additively into one proxy variable to avoid the misleading situation of reporting separate regressions when actually the two conditions are often comorbid. The World Bank data were used for GDP per capita (the natural logarithm of the GDP divided by the midyear population in current US dollars in 2010), health expenditure per capita (both public and private as a ratio of the total population) and Gini coefficient as a proxy for economic equity (the most recent year, which varies by country). ${ }^{18}$ Freedom House data were used for general ranking of political and civil freedom in 2012. ${ }^{19}$ Finally, the status of women was obtained from the United Nations Development Program Gender-Related Development Index (ratio of female to male Human Development Index value 2012). ${ }^{20}$

We also considered alternatives to the Rule of Law Index, all of which are less comprehensive, including (1) the 'rule of law' subcomponent of the Freedom House's Index of Civil Rights and Political Freedoms (comprising judicial independence, police under civilian control, protection from political terror, unjustified imprisonment, torture, war and insurgencies), ${ }^{19}$ (2) The 'rule of law' subcomponent of The Bertelsmann Stiftung's Transformation Index (State powers check 
and balance one another and ensure civil rights), ${ }^{21}$ and (3) the 'rule of law' subcomponent of the Worldwide Governance Indicators (captures perceptions of the extent to which agents have confidence in and abide by the rules of society and, in particular, the quality of contract enforcement, property rights, the police and the courts, as well as the likelihood of crime and violence)..$^{22} 23$

Other variables-such as population size, health expenditure per capita, non-communicable diseases (NCD) indicators such as for cancer or chronic obstructive pulmonary disease, or communicable disease indicators for AIDS, tuberculosis or malaria-were considered but not used in the analysis for reasons including a lack of association with health outcomes, colinearity with other variables, incomplete WHO data or pronounced regional distributions that would introduce confounding into a global-level analysis.

Analysis was done using IBM SPSS V.20.0 and Stata V.12.0. First, bivariate generalised negative binomial regressions of infant, maternal mortality and CVMR and DMR with rule of law were conducted. Second, multivariate generalised negative binomial models of infant, maternal and CVMR and DMR with GDP per capita, health expenditure per capita, freedom, Gini coefficient and status of women were calculated. Third, bivariate and multivariate ordinal regression models of life expectancy on the studied variables were conducted.
Fourth, bivariate and multivariate regression models of the health outcomes on the rule of law subindices were completed. Finally, the same regressions were conducted using other 'rule of law' measures (Freedom House, Bertelsmann Transformation Index and Worldwide Governance Indicators). The results of Levene's test showed that the assumption of homoscedasticity was not valid for the dependent variables, so appropriate generalised models of regressions were used.

Robustness tests were performed using both log transformed data and other data sources (not from the WHO or the World Bank) for infant and MMR, life expectancy, GDP per capita, Gini coefficient and health expenditure, as well as using the natural logarithm of the GDP per capita in the analyses. In these robustness tests, we obtained similar results as the ones presented below.

The study did not involve human subjects, and thus ethical approval was not required. We used publicly available data.

\section{RESULTS}

The mean score on the Rule of Law Index was 0.57 (range 0.34-0.89). Figure 1 presents scatter plots of rule of law (on the $\mathrm{x}$ axis) with the different health outcomes studied (on the y axis). Simply put, rule of law correlates negatively with adverse health outcomes-IMR, MMR and CVMR and DMR-but positively with LE.
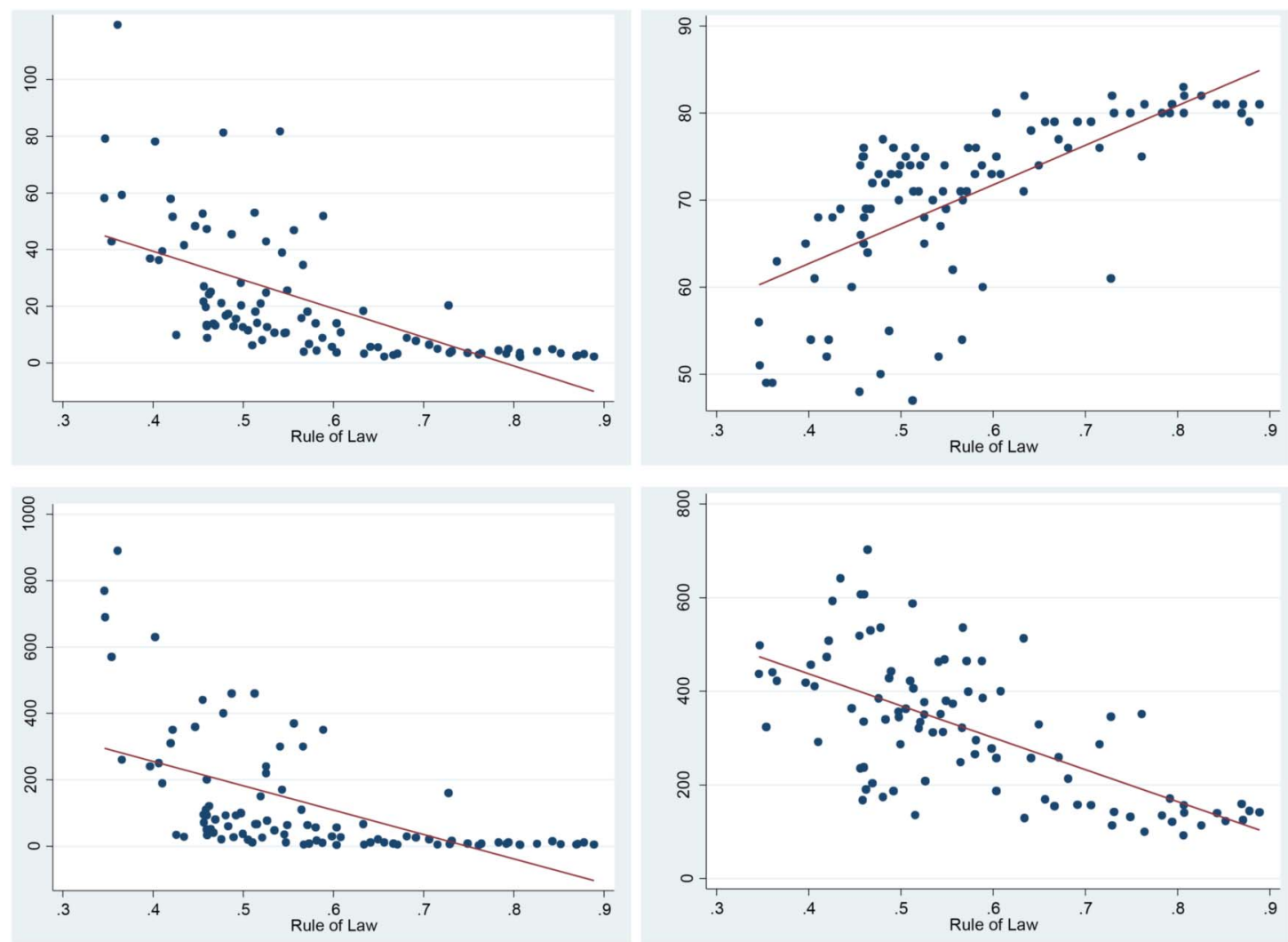

Figure 1 Scatter plots of rule of law with health outcomes. (A) Infant mortality, (B) maternal 562 mortality, (C) life expectancy and (D) cardiovascular disease and diabetes mortality. 
In regression models (table 2), the rule of law bivariate relationships with the studied health outcomes were statistically significant $(\mathrm{p}<0.000)$ and these relationships retained statistical significance $(\mathrm{p} \leq 0.05)$ when controlling for several obvious confounders (GDP per capita, health expenditure, freedom, Gini coefficient and status of women) with coefficients of -2.57 for infant mortality, -1.58 for maternal mortality, -1.13 for cardiovascular disease and diabetes and 4.93 for life expectancy, so we consider it unlikely that the effect is erroneous and attributable to one or several less obvious confounders rather than the rule of law itself.

The study of the rule of law index subfactors showed that in bivariate regressions, all eight subindices were significantly associated with IMR, MMR, CVMR+DMR and LE (table 3). Adjusting for Gini, GDP per capita, political and civil freedom, health expenditure and gender equality, the statistical significance remained only for some of the subindices depending on the health outcome. The rule of law factors associated with infant mortality were absence of Corruption and Criminal Justice, the ones associated with maternal mortality were Order and Security and Criminal Justice. For CVDMR and DMR, Limited Government Powers, Absence of Corruption, Fundamental Rights, Open Government, Regulatory Enforcement, Civil Justice and Criminal Justice were associated. Finally, life expectancy was associated with absence of Corruption, Fundamental Rights, Open Government and Regulatory Enforcement (see table 3).

All other rule of law measures were associated with all the health outcomes in bivariate analysis, but not all of these associations were robust when possible confounders (GDP per capita, health expenditure, freedom, Gini coefficient and status of women) were introduced (table 4).

\section{DISCUSSION}

We find that a country's adherence to the rule of law is strikingly well correlated with its overall national public health status, which suggests that the quality of institutions prevails over much else.
This study is the first to examine the role of the rule of law on the UN and WHO public health goals using a comprehensive rule of law index measured in a large sample, covering over $90 \%$ of the world's population. Our results can be simply put: the more that a country adheres to the rule of law, the more likely it is that it has a healthy population, whether defined by lower infant and MMR, CVDMR and DMR, or higher life expectancy, all of which are central to the UN's Millennium Development Goals or the WHO's Non-Communicable Disease Action Plan. Further, when using a comprehensive definition of the rule of law, these correlations are robust-they do not disappear following statistical adjustment-which demonstrates that the rule of law is associated with health in its own right, independent of the associations between countries' health status and their level of economic development, their health expenditures, their political freedoms, their economic inequality or the status of women. Further, these findings are robust in the sense that they were not dependent on any particular data set, and substituting the variables sourced from the WHO and the World Bank with comparable data from others yielded broadly similar results.

The association is particularly strong when a comprehensive measure of the rule of law is used in the models, that is, the WJP rule of law index that comprises eight thematic subindices: (1) Constraints on Government Powers; (2) Absence of Corruption; (3) Order and Security; (4) Fundamental Rights; (5) Open Government; (6) Regulatory Enforcement, (7) Civil Justice; and (8) Criminal Justice. ${ }^{17}$ This is the only global and cross-country comparable indicator that was specifically developed to measure the concept of the rule of law for a large sample of countries. Other available indicators were originally produced as a subcomponent of an instrument developed to measure a different concept: Governance (Worldwide Governance Indicators), ${ }^{22}$ Political Rights and Civil Liberties (Freedom House) ${ }^{19}$ and transition to democracy and a market economy (Bertelsmann Transformation Index). ${ }^{21}$

When individual subindices of the WJP Rule of Law Index are employed, or when narrower conceptions of the rule of law are used, some associations remained but

Table 2 Rule of law coefficients of Multivariate Regression Models of Health Outcomes on Rule of Law, gross domestic product per capita, Health expenditure, Freedom, Gini coefficient and status of women

\begin{tabular}{|c|c|c|c|c|c|c|}
\hline & \multicolumn{6}{|l|}{$95 \% \mathrm{Cl}$} \\
\hline & Coefficient & p Value & Low & High & LR $\chi^{2}$ & Pseudo $\mathbf{R}^{2}$ \\
\hline Infant mortality rate* & -2.57 & 0.032 & -4.93 & -0.22 & 44.23 & 0.15 \\
\hline Maternal mortality rate* & -1.58 & 0.050 & -3.25 & -0.08 & 43.17 & 0.12 \\
\hline Cardiovascular and diabetes mortality rate* & -1.13 & 0.009 & -1.97 & -2.81 & 66.17 & 0.05 \\
\hline Life expectancy & 4.93 & 0.045 & 0.14 & 11.72 & 92.86 & 0.15 \\
\hline
\end{tabular}

Number of observations 96.

*Generalised negative binomial regressions.

†Ordinal regression.

LR, likelihood ratio. 
Table 3 Regressions of IMR, MMR, CVMR and DMR and LE on each ROL factor

\begin{tabular}{|c|c|c|c|c|c|c|c|c|c|c|c|c|c|c|c|c|}
\hline & \multicolumn{12}{|c|}{ Generalised negative binomial regressions } & \multirow{2}{*}{\multicolumn{4}{|c|}{$\begin{array}{l}\text { Ordinal regressions } \\
\text { LE }\end{array}$}} \\
\hline & \multicolumn{4}{|l|}{ IMR } & \multicolumn{4}{|l|}{ MMR } & \multicolumn{4}{|c|}{ CVMR and DMR } & & & & \\
\hline & \multicolumn{2}{|l|}{ Raw } & \multicolumn{2}{|l|}{ Adjusted $^{*}$} & \multicolumn{2}{|l|}{ Raw } & \multicolumn{2}{|l|}{ Adjusted $^{*}$} & \multicolumn{2}{|l|}{$\overline{\text { Raw }}$} & \multicolumn{2}{|l|}{ Adjusted $^{*}$} & \multicolumn{2}{|l|}{ Raw } & \multicolumn{2}{|l|}{ Adjusted* } \\
\hline & Coefficient & $\begin{array}{l}\mathbf{p} \\
\text { Value }\end{array}$ & Coefficient & $\begin{array}{l}\mathbf{p} \\
\text { Value }\end{array}$ & Coefficient & $\begin{array}{l}p \\
\text { Value }\end{array}$ & Coefficient & $\begin{array}{l}p \\
\text { Value }\end{array}$ & Coefficient & $\begin{array}{l}\mathbf{p} \\
\text { Value }\end{array}$ & Coefficient & $\begin{array}{l}p \\
\text { Value }\end{array}$ & Coefficient & $\begin{array}{l}p \\
\text { Value }\end{array}$ & Coefficient & $\begin{array}{l}p \\
\text { Value }\end{array}$ \\
\hline $\begin{array}{l}\text { Limited } \\
\text { Government } \\
\text { Powers }\end{array}$ & -2.41 & 0.000 & -1.52 & 0.113 & -1.66 & 0.000 & -0.86 & 0.213 & -2.17 & 0.000 & -0.93 & 0.010 & 9.65 & 0.000 & 2.44 & 0.285 \\
\hline $\begin{array}{l}\text { Absence of } \\
\text { Corruption }\end{array}$ & -2.74 & 0.000 & -1.29 & 0.049 & -1.91 & 0.000 & -0.74 & 0.127 & -1.67 & 0.000 & -0.57 & 0.021 & 10.20 & 0.000 & 2.56 & 0.048 \\
\hline $\begin{array}{l}\text { Order and } \\
\text { Security }\end{array}$ & -2.60 & 0.000 & -0.99 & 0.169 & -2.23 & 0.000 & -0.89 & 0.05 & -1.26 & 0.001 & -0.15 & 0.646 & 9.31 & 0.000 & 3.29 & 0.124 \\
\hline $\begin{array}{l}\text { Fundamental } \\
\text { Rights }\end{array}$ & -2.88 & 0.000 & -1.59 & 0.092 & -2.06 & 0.000 & -1.17 & 0.162 & -2.36 & 0.000 & -1.20 & 0.012 & 12.18 & 0.000 & 6.64 & 0.031 \\
\hline $\begin{array}{l}\text { Open } \\
\text { Government }\end{array}$ & -3.49 & 0.000 & -1.37 & 0.191 & -2.33 & 0.000 & -0.70 & 0.337 & -2.37 & 0.000 & -1.09 & 0.002 & 14.52 & 0.000 & 6.82 & 0.007 \\
\hline $\begin{array}{l}\text { Regulatory } \\
\text { Enforcement }\end{array}$ & -3.29 & 0.000 & -1.00 & 0.274 & -2.43 & 0.000 & -0.76 & 0.244 & -2.31 & 0.000 & -0.85 & 0.011 & 13.67 & 0.000 & 3.77 & 0.041 \\
\hline Civil Justice & -3.34 & 0.000 & -0.95 & 0.275 & -2.62 & 0.000 & -0.87 & 0.185 & -2.25 & 0.000 & -0.85 & 0.011 & 11.99 & 0.000 & 1.09 & 0.572 \\
\hline Criminal Justice & -3.19 & 0.000 & -1.54 & 0.040 & -2.34 & 0.000 & -0.91 & 0.042 & -1.94 & 0.000 & -0.70 & 0.018 & 10.10 & 0.000 & 2.01 & 0.297 \\
\hline
\end{tabular}

${ }^{*}$ Controlling by Gini, GDPpc, Freedom, Health Expenditure and status of women.

CVMR, cardiovascular mortality rate; DMR, diabetes mortality rate; GDPpc, gross domestic product per capita; IMR, infant mortality rate; LE, life expectancy at birth; MMR, maternal mortality

rate; $\mathrm{ROL}$, rule of law. 


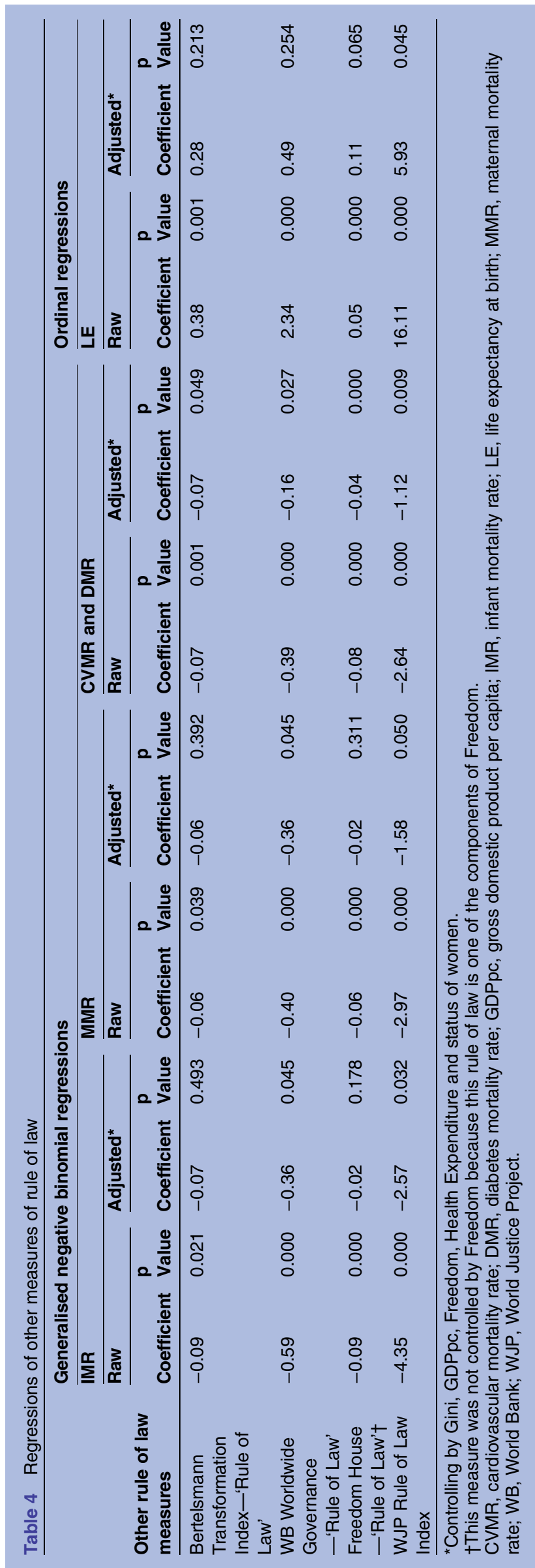

others disappeared. Our interpretation of this finding is that rule of law is like a complete body. Just as the health of an individual does not depend solely on a functioning heart, lungs or kidneys, but on a homeostatic balance among them, the relationship between legal systems and population health is intricate and may be severely damaged by any one failing dimension of the rule of law.

Moreover, our findings suggest that the relation between the rule of law and health outcomes is not governed by related concepts, such as democracy or human rights-our measurement of freedom (defined as political rights and civil liberties) is not robust in our models.

Why should the rule of law matter to healthy societies when it seems so far removed from medical practice? To use a loose biological analogy, law provides homeostasis. Laws by their wording form a code (rather like DNA) that specifies governance structures (cellular machinery) and shapes public and private behaviour both positively and negatively (cellular regulation). Applied to the whole of society (the body), the legal code and its structures contribute to myriad life-sustaining activities: for example, design of health systems; licensing of health professionals; protection of the environment and salubrious air and water; effective public health responses to pandemic infectious diseases; regulation of drugs and medical devices; reduction of risk factors like tobacco and alcohol; and criminalisation of violent behaviour. The homeostatic condition is maintained by wilful policy decisions and 'nudges' from government (the nervous system), but can be perturbed by various destabilising causes (pathogens) whose damage the law tries to limit through the policing system (the immune system) followed by a system of restorative justice (wound healing). Of course, one must be very careful not to overinterpret these inexact analogies, and merely view them as a useful thought bridge spanning the very different disciplines of law and health.

Do the correlations observed in this study evince an underlying causality, where development of the rule of law somehow improves health outcomes? The design of the study does not permit causality to be inferred, but we propose here three plausible causal mechanisms, borne out in other studies, that lead us to believe the answer to this question is yes: (1) Corruption; (2) Enforcement of Health Rights and (3) Equity or Social Justice. The first mechanism posits that weak laws and law enforcement facilitate a high prevalence of corruption, which acts as a brake on health outcomes because diversion of health resources for personal gain directly subtracts from the delivery of health services to the population. ${ }^{24}$ The second mechanism posits that when core health services or entitlements become institutionalised through law, whether by governments' legislation or plaintiffs' litigation, the medical or public health standard of care becomes legally binding and mandatory rather than ethically binding and hortatory. ${ }^{25-31}$ The third mechanism posits that legal frameworks that 
tolerate or force unequal standing among segments of the population are likely to achieve unequal health outcomes, which are reversible through changes to the discriminatory legal framework itself. ${ }^{32} 33$

These three mechanisms are not in competition with one another; rather, they are cumulative or synergistic. Countries that score poorly in the Rule of Law Index can be simultaneously corrupt, inequitable and disinclined to devise or enforce laws for health. Likewise, they can score poorly on most or even all of the subindices. Since our data demonstrate that all of the eight subindices independently correlate with one or more health outcomes, this is suggestive that any causal connection between the rule of law and health outcomes is mediated through multiple mechanisms-the three we suggest here, and probably also others for which a case can be made (eg, transparency, accountability).

Further, we believe this study requires a re-evaluation of the relationships between economic development and good health-is law actually a determinant of both? As already mentioned, studies associate the rule of law with economic development, ${ }^{13} 15163435$ in some cases so powerfully that, as Rodrik et $a l^{14}$ write, 'the quality of institutions trumps everything else.' If that is right, the received wisdom of other studies that 'macro' economic development is itself a correlate of good health, ${ }^{2} 36-40$ and 'micro' economic inequality is itself a correlate of poor health, ${ }^{28} 2941-45$ may be missing a third dimension, for both of these associations might depend on the rule of law shaping the economic conditions. That possibility, regrettably, is actively discounted in the studies cited here: none used the rule of law as a control variable. Therefore, caution must be exercised to avoid the fallacy that if economic development correlates with both health and the rule of law, then it must be paramount and determine both. ${ }^{46}$

We instead take the view that law sits in a triangular relationship with wealth and health, and provides the mechanisms that allow wealth to be earned honestly and distributed equitably so as to be expended on health (and this should be viewed against the counterfactual of wealth earned corruptly and distributed inequitably, which leaves little to be expended on health and results in poor outcomes). The triangular relationship is consistent with this study's results, and the argument of Rodrik et $a l^{14}$ that law and institutions trump where development is concerned. The same seems true for heath, although not enough is known about the mechanisms through which some of the subindices of the rule of law correlate positively.

Our study is the first to explore the association of a comprehensive rule of law indicator (the Rule of Law Index) with health outcomes, so naturally it has limitations. Above all, we repeat that correlation is not causation, though plausible causal mechanisms exist. We also acknowledge that in using a national level of analysis, there can be variations in the rule of law within countries (particularly federal states) that are unaccounted for. This study design is cross-sectional because of data limitations, but future studies will be able to use several years of the Rule of Law Index in a transverse design, now that the survey methods are mature and data collection is ongoing. Future studies could also draw on what are likely to be fuller and more accurate health metrics, particularly for the NCDs which are emerging.

We conclude that the rule of law is a hitherto undervalued, extremely underutilised point of intervention for public health improvements. For example, the WHO's Rio Political Declaration on Social Determinants of Health omits any mention of law at all. We believe that the WHO should consider the establishment of a Commission on Law and Health, as it did the Commission on Macroeconomics and Health, with a mandate to acquire further evidence and advocate putting law at the service of health.

Contributors AMP-R, AA, JCB and AMR-S contributed to the conception and design of the work, the analysis and the interpretation of data, the drafting of the manuscript and the approval of the final version.

Funding This research received no specific grant from any funding agency in the public, commercial or not-for-profit sectors.

Competing interests Their time was paid by their employers, Universidad del Rosario, the Government of Canada and the World Justice Project.

Provenance and peer review Not commissioned; externally peer reviewed.

Data sharing statement Additional data can be accessed via the Dryad data repository at http://datadryad.org/with the doi:10.5061/dryad.tq480.

Open Access This is an Open Access article distributed in accordance with the Creative Commons Attribution Non Commercial (CC BY-NC 4.0) license, which permits others to distribute, remix, adapt, build upon this work noncommercially, and license their derivative works on different terms, provided the original work is properly cited and the use is non-commercial. See: http:// creativecommons.org/licenses/by-nc/4.0/

\section{REFERENCES}

1. Berkman LF, Kawachi I, Glymou M. Social epidemiology. 2nd edn. New York: Oxford University Press, 2014.

2. Sachs JD, Ahluwalia IJ, Amoako K, et al. Macroeconomics and health: investing in health for economic development. Geneva: World Health Organization, 2001.

3. Bingham T. The rule of law. London: Penguin Books, 2011.

4. Kleinfeld R. Advancing the rule of law abroad. Washington DC: Carnegie Endowment for International Peace, 2012.

5. Timmer A, Goldschmidt J, Buyse A, et al. Report state-of-the-art literature review human rights, democracy and the rule of law [Internet]. Frame-EU, November 2013 (cited 20 Febuary 2015) Report No. 1 Work Package No. 3 Large-Scale FP7 Collaborative Project GA No. 3200001 May 2013-30 April 2017. http://www.fp7-frame.eu/wp-content/materiale/reports/ 01-Deliverable-3.1.pdf

6. Berg LA, Desai D. Background Paper: Overview on the Rule of Law and Sustainable Development for the Global Dialogue on Rule of Law and the Post-2015 Development Agenda. Georgetown and Harvard Law School. Draft, August 2013. http://www.undp.org/ content/dam/undp/library/Democratic\%20Governance/Access\%20to \%20Justice\%20and\%20Rule\%20of\%20Law/Global\%20Dialogue\% 20Background\%20Paper\%20-\%20Rule\%20 of\%20Law\%20and\% 20Sustainable\%20Developme....pdf

7. Roseveare $\mathrm{C}$. The rule of law and international development. London, UK: Department for International Development (DFID), 2013. http://r4d.dfid.gov.uk/Output/192962/

8. Pech L. Rule of law as a guiding principle of the European Union's External Action. CLEER Working Papers 2012/3. T.M.C. The Hague: Asser Institute, 2012. 
9. Weinganst $\mathrm{B}$. Why developing countries prove so resistant to the rule of law. In: Heckman J, Nelson R, Cabatingan L, eds. Global perspectives on the rule of law. London and New York: Rutledge, 2010:28-51.

10. Ahmad Y, Dougherty A, Kleinfeld R, et al. Reducing Violence and Improving the Rule of Law. Carnegie Endowment for International Peace and The World Justice Project, September 2014 (cited 18 Febuary 2015). http://carnegieendowment.org/files/Violence_lit_ review.pdf

11. Ginsburg T. Pitfalls of measuring the rule of law. Hague J Rule Law 2011;3:269-80.

12. Barendrecht M. Rule of law, measuring and accountability: problems to be solved bottom up. Hague J Rule Law 2011;3:281-304.

13. Kaufmann D, Kraay A. Growth without Governance. World Bank Policy Research Working Paper, No. 2928. Washington DC: World Bank, 2002. Available at SSRN. http://ssrn.com/abstract=316861

14. Rodrik D, Subramanian A, Trebbi F. Institutions Rule: The Primacy of Institutions Over Geography and Integration in Economic Development. NBER Working Paper, No. w9305. Cambridge, MA: The National Bureau of Economic Research, 2002. Available at SSRN. http://ssrn.com/abstract $=347077$

15. Rigobon R, Rodrik D. Rule of law, democracy, opennness, and income: sstimating the interrelationships. NBER Working Paper, No. w10750. Cambridge, MA: The National Bureau of Economic Research, 2004. Available at NBER. http://www.nber.org/papers/ w10750

16. Haggard S, Macintyre A, Tiede L. The rule of law and economic development annu. Rev Polit Sci 2008;11:20-53.

17. Agrast M, Botero J, Martinez J, et al. World justice project rule of law index 2012-2013. Washington DC: The World Justice Project, 2012.

18. The world Bank. Data. Indicators. http://data.worldbank.org/indicator (accessed Jan 2013).

19. Freedom House. Freedom in the world, 2012. http://www. freedomhouse.org/report/freedom-world/freedom-world-2012 (accessed Jan 2013)

20. United Nations Development Program. Human Development Report Gender-Related Development Index. http://hdr.undp.org/en/content/ gender-development-index-gdi (accessed Feb 2015).

21. Bertelsmann Stiftung. Transformation index BTI 2013. http://www. bti-project.org/bti-home/ (accessed Sep 2014).

22. The World Bank Group. The Worldwide Governance Indicators (WGI) project. http://info.worldbank.org/governance/wgi/index. aspx\#home (accessed Sep 2014).

23. Kaufmann D, Kraay A, Mastruzzi M. The worldwide governance indicators: methodology and analytical issues. Hague J Rule Law 2011;3:220-46.

24. Trebilcock M, Daniels R. Rule of law reform and development: charting the fragile path of Progress. Cheltenham, UK; Northhampton, MA: Edward Elgar, 2008.

25. Gostin LO. Public health law in a new century. part I: law as a tool to advance the community's health. JAMA 2000;283:2837-41.

26. Gostin LO. Public health law in a new century: part II: public health powers and limits. JAMA 2000;283:2979-84.

27. Sen A. Development as freedom. Oxford: Oxford University Press, 1999.

28. Attaran A, Pang T, Whitworth J, et al. Healthy by law: the missed opportunity to use laws for public health. Lancet 2012;379:283-5.

29. Backman $G$, Hunt $P$, Khosla $R$, et al. Health systems and the right to health: an assessment of 194 countries. Lancet 2008;372:2047-85.
30. Franco A, Alvarez-Dardet C, Ruiz M. Effect of democracy on health: ecological study. BMJ 2004;329:1421-3.

31. Besley T, Kudamatsu M. Health and Democracy. Am Econ Rev 2006;96:313-18.

32. Dwyer J. Global Health and Justice. Bioethics 2005;19:460-75.

33. Coovadia $\mathrm{H}$, Jewkes $\mathrm{R}$, Barron $\mathrm{P}$, et al. The health and health system of South Africa: historical roots of current public health challenges. Lancet 2009;374:817-34.

34. Barro R. Determinants of economic growth: a cross-country empirical study. Boston, MA: MIT Press, 1997.

35. Sala-i-Martin X. I Just Ran Two Million Regression. Am Econ Rev 1997;87:178-83.

36. Renton A, Wall M, Lintott J. Economic growth and decline in mortality in developing countries: an analysis of the World Bank development datasets. Public Health 2012;126:551-60.

37. Schell CO, Reilly $\mathrm{M}$, Rosling $\mathrm{H}$, et al. Socioeconomic determinants of infant mortality: a worldwide study of 152 low-, middle-, and high-income countries. Scand J Public Health 2007;35: 288-97.

38. Biggs B, King L, Basu S, et al. Is wealthier always healthier? The impact of national income level, inequality, and poverty on public health in Latin America. Soc Sci Med 2010;71:266-73.

39. Ensor T, Cooper S, Davidson L, et al. The impact of economic recession on maternal and infant mortality: lessons from history. BMC Public Health 2010;10:727.

40. Palmer A, Tomkinson J, Phung C, et al. Does ratification of human-rights treaties have effects on population health? Lancet 2009;373:1987-92

41. Navarro $P$, Whitehead M, Doran $T$, et al. Summary and conclusions of the study. In: Navarro V, ed. The polictical and social context of health. Amityville, NY: Baywood Publishing Company, 2004: 221-6.

42. Wilkinson R, Pickett K. Income inequality and population health: a review and explanation of the evidence. Soc Sci Med 2006;62:1768-84.

43. Starfield B. Pathways of influence on equity in health. Soc Sci Med 2007;64:1355-62.

44. Macinko JA, Shi L, Starfield B. Wage inequality, the health system, and infant mortality in wealthy industrialized countries, 1970-1996. Soc Sci Med 2004;58:279-92.

45. Spencer $\mathrm{N}$. The effect of income inequality and macro-level social policy on infant mortality and low birthweight in developed countries -a preliminary systematic review. Child Care Health Dev 2004;30:699-709.

46. Boettke P, Subrick J. Rule of law, development, and human capabilities. In: Zywicki T, ed. The rule of law, freedom, and prosperity. 10. Chicago, IL: University of Chicago Press, 2003:109-26.

47. Transparency International. Global corruption report. London: Pluto Press, 2006.

48. Canada (Attorney General) v. PHS Community Services Society, 2011 SCC 44, [2011] 3 S.C.R. 134.

49. Mobaraki AE, Söderfeldt B. Gender inequity in Saudi Arabia and its role in public health. East Mediterr Health J 2010;16:113-18.

50. Murli S. Deora vs Union Of India And Ors on 2 November, 2001 Supp(4) SCR 650.

51. Rasella D, Aquino R, Santos CA, et al. Effect of a conditional cash transfer programme on childhood mortality: a nationwide analysis of Brazilian municipalities. Lancet 2013;382:57-64. 